A.F.L. Paschoal

https://orcid.org/0000-0002-9245-7117 J.T. Santos

https://orcid.org/0000-0002-3079-030 A.P.G. Mellagi

\section{Use of testicular tone and echogenicity in identifying boars with low} sperm quality

\author{
[Uso de tônus e ecogenicidade testiculares na identificação de reprodutores \\ suínos com baixa qualidade espermática] \\ A.F.L. Paschoal ${ }^{1}$, J.T. Santos ${ }^{1}$, A.P.G. Mellagi ${ }^{2}$, M.L. Bernardi ${ }^{3}$, \\ I. Wentz $^{2}$, F.P. Bortolozzo ${ }^{2^{*}}$ \\ ${ }^{1}$ aluno de pós-graduação - Faculdade de Veterinária - Universidade Federal do Rio Grande do Sul - Porto Alegre, \\ RS \\ ${ }^{2}$ Faculdade de Veterinária - Universidade Federal do Rio Grande do Sul - Porto Alegre, RS \\ ${ }^{3}$ Faculdade de Agronomia - Universidade Federal do Rio Grande do Sul - Porto Alegre, RS
}

https://orcid.org/0000-0002-0296-5637

M.L. Bernardi

https://orcid.org/ 0000-0003-2543-5556 Wentz

https://orcid.org/0000-0003-1709-1474

F.P. Bortolozzo

https://orcid.org/0000-0001-5302-328X

\begin{abstract}
This study aimed to evaluate the use of some testicular traits to identify boars with low sperm morphological quality. The consistency (scores from 1 to 5), tone with tonometry (mm), parenchyma echogenicity and heterogeneity with ultrasound (pixel) were assessed in 402 mature boars (18.5 months on average). Sperm abnormality thresholds ( $\leq 25 \%$ of total sperm abnormalities, $\leq 5 \%$ of heads, acrosome, neck or midpiece defects, $\leq 10 \%$ tail defects, and $15 \%$ cytoplasmic droplets) were used to classify boars as approved or disapproved. Three classes of testicular traits were formed (extremely low and high values, approximately $15 \%$ each, were kept in separated classes). When the traits were individually evaluated, fewer boars were approved if the echogenicity or heterogeneity were high, or if the tone was rigid. When evaluated in combination, the interaction between heterogeneity and tone, and between heterogeneity and echogenicity were significant. The high heterogeneity combined with soft tone or with hypo-echogenicity resulted in lower approval of boars. Tonometry and ultrasonography have a moderate potential to be included in breeding soundness examination of boars. When combined, they provide more reliable information about the impact of testicular parenchymal alterations on morphology of sperm cells.
\end{abstract}

Keywords: andrology, breeding soundness, consistency, echotexture, morphology, spermatozoa

\title{
RESUMO
}

O estudo objetivou avaliar o uso de características testiculares para identificar reprodutores com baixa qualidade de morfologia espermática. A consistência (escore de 1 a 5), o tônus por tonometria (mm), a ecogenicidade e a heterogeneidade do parênquima testicular por ultrassonografia (pixel) foram avaliados em 402 machos suínos maduros (18,5 meses, em média). Limiares máximos de anormalidades espermáticas $(\leq$ $25 \%$ de defeitos totais, $\leq 5 \%$ de defeitos de cabeça, acrossoma, colo e peça intermediária, $\leq 10 \%$ de defeitos de cauda e $15 \%$ de gota citoplasmática) foram utilizados para classificar os machos como aprovados ou reprovados. Três classes de características testiculares foram formadas (valores extremamente baixos e altos, aproximadamente $15 \% \mathrm{em}$ cada, foram mantidos em classes separadas). Quando as características testiculares foram avaliadas individualmente, menos machos foram aprovados se a ecogenicidade ou a heterogeneidade foram altas, ou se o tônus era rígido. Quando avaliadas em combinação, a interação entre heterogeneidade e tônus e a interação entre heterogeneidade e ecogenicidade foram significativas. A alta heterogeneidade combinada com testículos flácidos ou com testículos hipoecogênicos resultou em menor aprovação de cachaços. A tonometria e a ultrassonografia possuem potencial moderado para serem incluídas no exame andrológico de cachaços. Quando combinadas, as técnicas fornecem uma informação mais consistente do impacto das alterações do parênquima testicular na morfologia das células espermáticas.

Palavras-chave: andrologia, avaliação andrológica, consistência, ecotextura, morfologia, espermatozoides

Recebido em 5 de junho de 2018

Aceito em 11 de dezembro de 2018

* Autor para correspondência (corresponding author)

E-mail: fpbortol@ufrgs.br 


\section{INTRODUCTION}

Assessing boar performance for early culling is important for achieving better reproductive results and for cost reduction. One of the most common reasons for culling is low quality of sperm, including poor sperm morphology (Knox et al., 2008), which can affect the farrowing rate and litter size (Flowers, 1997). Therefore, it is vital to evaluate the reproductive efficiency of boars, due to their large impact on herd productivity. Although breeding soundness examination is an important preliminary method to evaluate boar performance, this routine is frequently neglected in studs.

Breeding soundness examination includes history and clinical evaluation, which assesses the locomotion system, testes, scrotum, penis, and epididymis of a boar. Testicular consistency is an accepted sperm quality indicator in bulls (Hahn et al., 1969) and the degenerative process of testes has been associated with disturbances in spermatogenesis (Coulter and Foote, 1979; Van Camp, 1997). Acute degeneration may cause testes softness while chronic degeneration may result in stiffness due to fibrosis. Although manual palpation is commonly used to assess testicular consistency, the method is subjective. The use of tonometer to graduate the testicular consistency was first described in bulls by Hahn et al. (1969), being considered a highly repeatable measurement, regardless of the examiners.

Real-time ultrasonographic evaluation is a noninvasive method that can be applied as a complementary test in the breeding soundness examination. The use of B-mode ultrasound has been reported in boars for investigating sperm production (Clark et al., 2003), puberty phases (Ford and Wise, 2011), and sperm quality of animals with hydrocele (Caspari et al., 2012). In a recent investigation, Pinho et al. (2018) reported no difference in pixel intensity of the testicular parenchyma among four pig breeds.

Sperm morphology is routinely examined in studs as an indicator of sperm quality status. However, there is a lack of information associating sperm abnormalities with testicular tone or real-time ultrasound scanning. The aim of the current study was to evaluate testicular traits such as consistency (through manual palpation and tonometry) and parenchyma ultrasound imaging (real-time ultrasonography), as potential methods to classify boars according to their sperm morphology.

\section{MATERIAL AND METHODS}

The study was conducted in five studs from Santa Catarina and Rio Grande do Sul states in Brazil, during the months of July and August, in accordance with the Ethics Committee on the Use of Animals of Federal University of Rio Grande do Sul (protocol number 31329).

Four hundred and two adult and healthy boars from studs A, B, C, D, and E (50, 121, 94, 85 and 52 boars, respectively), with a different genetic line each, were examined. Mean age $( \pm$ SE) of boars was $18.5 \pm 0.44$ months. All boars were under weekly semen collection routine and housed in individual crates ranging from 0.65 to $0.70 \mathrm{~m}$ in width and 2.2 to $2.4 \mathrm{~m}$ in length. Access to water was ad libitum and boars were under the same nutritional management with corn and soybean-based diet $(2.1$ to $2.4 \mathrm{~kg}$ per day, $15 \%$ crude protein, $0.55 \%$ digestible lysine and $3300 \mathrm{kcal} \mathrm{ME} / \mathrm{kg}$ ).

Two methods (manual palpation and tonometry) were used to assess the testicular consistency. The exams were performed by the same experienced examiner. Manual palpation of testes was performed to assess their consistency and subjective scoring, from 1 to 5 , according to the Brazilian College of Animal Reproduction (Manual..., 2013). A lower score (1) was attributed to very soft, and a higher score (5) to very rigid testes.

For the evaluation of tone, a digital tonometer (Starrett®, model 3600, Athol, MA, USA) was used, with a scale of 0 to $12 \mathrm{~mm}$, after adaptations by the Mechanic Laboratory of Physics Institute - UFRGS. This method was adapted from that described by Hahn et al. (1969). The tonometer was positioned on the middle region of each testicle and pressed against the testicular surface perpendicular to the caudal surface of the organ, causing a deflection of the metal stem. Each testicle was measured four times at the same region and the average of the measurements was used for the statistical analysis. 
All testicular examinations were performed by the same examiner using a B-mode portable ultrasound (Mindray ${ }^{\circledR}$, DP2200 Vet, Shenzhen Mindray Bio-Medical Electronics Co., Nanshan, China) and a $7.5 \mathrm{MHz}$ linear array transducer (Mindray ${ }^{\circledR}$, 75L50EAVet, Shenzhen Mindray Bio-Medical Electronics Co., Nanshan, China). The transducer was positioned on the midpoint of each testicle, perpendicular to the longitudinal axis of the organ, on the caudal surface. Ultrasonographic images were captured when the mediastinum and tunica albuginea were clearly visible (Ford and Wise, 2011).

Image J software (National Institute of Health, USA) was used for further analysis of testicular parenchyma echogenicity (intensity of pixels, from 0 to 255) and heterogeneity (standard deviation of the echogenicity). A representative area of $200 \mathrm{~mm}^{2}$ (Pinho et al., 2018) was selected on the caudal pole of each testicle, which excluded mediastinum, scrotum, tunics, and epididymis (Clark et al., 2003).

One raw semen sample $(20 \mu \mathrm{L})$ of each boar was fixed in $2.0 \mathrm{~mL}$ of formalin-citrate solution (2.94\%). Two hundred spermatozoa per sample were evaluated using phase-contrast microscopy (1000x total magnification Olympus, model BX41, Olympus Latin America Inc., Miami, USA). Sperm defects in head, acrosome, neck, intermediate piece or tail (bent and coiled), and the presence of cytoplasmic droplets (proximal and distal) (Shipley, 1999) were recorded.

Boars were classified as "approved" or "disapproved" based on sperm morphological findings. Boars considered approved showed $\leq$ $25 \%$ of total sperm abnormalities, $\leq 5 \%$ abnormal sperm heads, $\leq 5 \%$ acrosome defects, $\leq 5 \%$ neck defects and $\leq 5 \%$ midpiece defects, maximum of $10 \%$ tail defect and $15 \%$ cytoplasmic droplets. Those classified as disapproved did not meet the criteria of semen guidelines (Waberski et al., 1994; Manual..., 2013; Althouse, 2014).

All statistical analyses were performed using the 9.3 version of SAS software (SAS Institute, Inc.,
Cary, NC). The differences were considered significant if $\mathrm{P} \leq 0.05$ and tendency if $\mathrm{P}>0.05$ and $\mathrm{P} \leq 0.10$. For all the testicular traits, the average value of left and right measurements was used for statistical analysis.

In the first analysis, the correlation coefficients among testicular traits, and between testicular traits and total spermatozoa abnormalities were obtained (PROC CORR). Pearson's coefficient was used for tone, echogenicity, and heterogeneity, whereas the Spearman's coefficient was used for the results of manual palpation. In addition, analyses of variance (PROC GLIMMIX) were performed to determine whether there were any differences in testicular traits, between approved and disapproved boars. The consistency observed by manual palpation was compared between approved and disapproved boars assuming a multinomial ordinal distribution (PROC GLIMMIX).

Logistic regression models (PROC GLIMMIX) were used to investigate the effect of testicular traits on approval of boars. The approval of boars was coded as a binary response variable, i.e., approved or disapproved. Models were run with testicular traits individually included as continuous independent variables. In addition, other models were run with testicular traits investigated as categorical variables. For each testicular trait, boars were allocated in three classes, thereby keeping boars with extremely low and high values (approximately 15\% each) in separated classes (Table 1). In all logistic regression models, the testicular traits (continuous or classes) were included as fixed effects. The possible effect of the variation among studs was considered by including the stud as a random factor.

Receiver-operating curves (ROC) were used to determine the overall discriminant power of testicular traits that were significant in logistic regression models. The cut-off value for approval of boars was calculated only for the significant testicular traits. 
Table 1. Classes of testicular consistency, tone, echogenicity, and heterogeneity of 402 boars examined in five different studs

\begin{tabular}{cccc}
\hline Item & Class 1 & Class 2 & Class 3 \\
\hline \multirow{2}{*}{ Consistency (score 1-5) } & $1.0-2.00$ & $2.25-3.00$ & $3.25-4.50$ \\
& $\mathrm{n}=67$ & $\mathrm{n}=287$ & $\mathrm{n}=48$ \\
Tone (mm) & $2.68-4.00$ & $4.01-5.89$ & $5.90-7.80$ \\
& $\mathrm{n}=62$ & $\mathrm{n}=276$ & $\mathrm{n}=64$ \\
Echogenicity (pixel) & $40.90-63.99$ & $64.00-93.99$ & $94.00-121.95$ \\
& $\mathrm{n}=64$ & $\mathrm{n}=276$ & $\mathrm{n}=62$ \\
Heterogeneity (pixel) & $10.40-15.24$ & $15.25-19.54$ & $19.55-25.25$ \\
& $\mathrm{n}=61$ & $\mathrm{n}=280$ & $\mathrm{n}=61$ \\
\hline
\end{tabular}

\section{RESULTS}

The overall mean values (mean \pm SE) of consistency by manual palpation and by tonometry were $2.74 \pm 0.02$ and $4.99 \pm 0.04 \mathrm{~mm}$, respectively. Mean values for echogenicity and heterogeneity were $79.11 \pm 0.74$ and $17.46 \pm 0.11$ pixels, respectively. The percentage of total sperm defects and each abnormality is shown in Figure 1. The presence of cytoplasmic droplets was the major abnormality, followed by tail defects.

Based on sperm morphology guidelines, $40.30 \%$ of boars were considered disapproved, the exceeded thresholds of total abnormalities and cytoplasmic droplets (Figure 2) being the primary cause. More than $15 \%$ of boars were not approved due to the exceeded thresholds of total abnormalities and tail defects. The increased presence of cytoplasmic droplets led to the disapproval of approximately $12 \%$ of boars.
The tone was moderately correlated with the consistency by manual palpation $(\mathrm{r}=0.62 ; \mathrm{P}<$ $0.0001)$ and weakly correlated with the echogenicity of testicular parenchyma $(r=0.11$; $\mathrm{P}=0.03)$. The heterogeneity of testicular parenchyma was weakly correlated with echogenicity $(\mathrm{r}=0.39 ; \mathrm{P}<0.0001)$, and with sperm abnormalities $(\mathrm{r}=0.10 ; \mathrm{P}=0.03)$. The heterogeneity of testicular parenchyma was significantly $(\mathrm{P}=0.01)$ lower in approved than in disapproved boars. The other testicular traits were not different between approved and disapproved boars (Table 2).

The percentage of approved boars for each class of testicular trait is shown in Table 3. When tested as a categorical variable, tone affected $(\mathrm{P}=$ 0.02 ) the percentage of approved boars. A lower percentage of boars was approved in class 3 (higher tone) than in class $1(\mathrm{P}=0.05)$ and class 2 $(\mathrm{P}=0.004)$. Boars with more echogenic testes (class 3) tended $(\mathrm{P}=0.10)$ to have a lower approval rate than those with less echogenic testes (class 1).

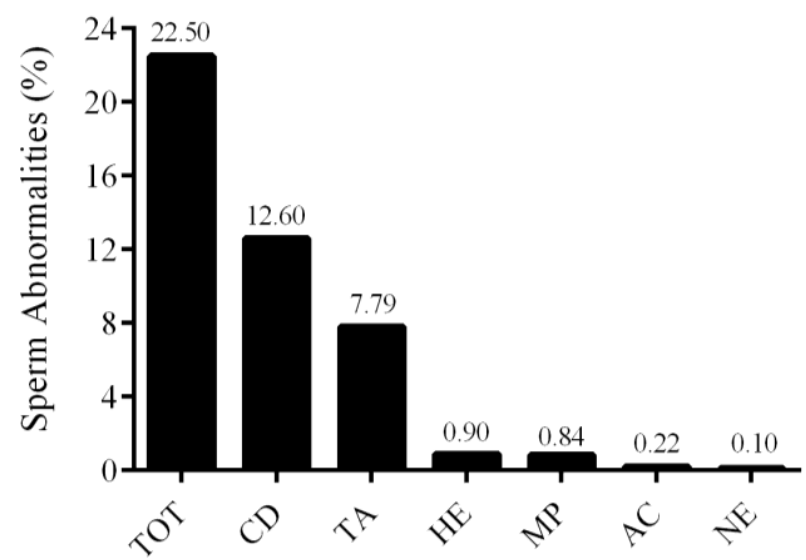

Figure 1. Frequency (\%) of sperm abnormalities in 402 boars of five different studs (total sperm abnormalities-TOT; cytoplasmic droplets-CD; tail defects-TA; abnormal heads-HE; midpiece defectsMP; acrosome defects-AC; and neck defects-NE). 


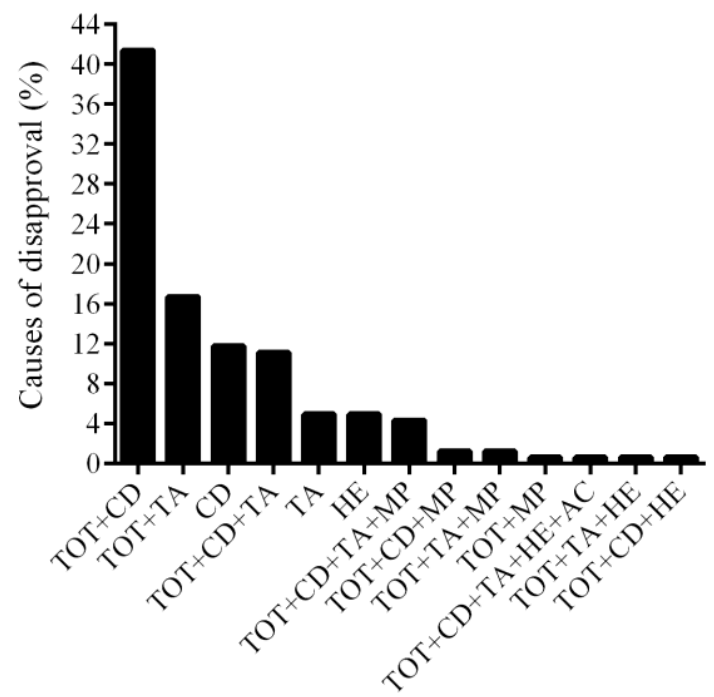

Figure 2. Frequency (\%) of causes for the disapproval of boars, according to the criteria guidelines of sperm morphology (exceeding the threshold of total sperm abnormalities -TOT, cytoplasmic droplets CD or abnormalities of tail - TA, head - HE, midpiece- MP, and acrosome - AC).

Table 2. Testicular traits (means \pm SE) of the approved $(n=240)$ and disapproved boars $(n=162)$ based on sperm abnormality thresholds

\begin{tabular}{cccc}
\hline Item & Approved & Disapproved & P value \\
\hline Consistency (score 1 - 5)* & $2.76(1.0-3.0-4.0)$ & $2.71(1.5-3.0-4.0)$ & 0.99 \\
Tone (mm) & $5.03(0.17)$ & $5.17(0.17)$ & 0.12 \\
Echogenicity (pixel) & $79.42(3.20)$ & $81.11(3.26)$ & 0.26 \\
Heterogeneity (pixel) & $17.06(0.49)$ & $17.59(0.49)$ & 0.01 \\
\hline
\end{tabular}

*Value expressed as mean (minimum-median-maximum). Sperm abnormality thresholds to classify boars as approved and disapproved included $\leq 25 \%$ of total sperm abnormalities, $\leq 5 \%$ of heads, acrosome, neck or midpiece defects, with a maximum of $10 \%$ tail defect and $15 \%$ of cytoplasmic droplet.

Table 3. Percentage of approved boars, based on sperm abnormality thresholds, according to testicular trait classes

\begin{tabular}{lcccc}
\hline Testicular trait & Class 1 (\%) & Class 2 (\%) & Class 3 (\%) & P value \\
\hline Consistency (score 1 5) & 55.22 & 61.32 & 56.25 & 0.78 \\
Tone (mm) & $56.45^{\mathrm{a}}$ & $64.86^{\mathrm{a}}$ & $40.63^{\mathrm{b}}$ & 0.02 \\
Echogenicity (pixel) & $67.19^{\mathrm{c}}$ & $61.59^{\mathrm{cd}}$ & $43.55 \mathrm{~d}^{\mathrm{d}}$ & 0.10 \\
Heterogeneity (pixel) & 67.21 & 59.29 & 54.10 & 0.16 \\
\hline
\end{tabular}

Consistency (score): Class 1: 1 - 2; Class 2: 2.25 - 3; Class 3: 3.25 - 4.5. Tone: Class 1: 2.68 - 4.00mm; Class 2: 4.01 - 5.89mm; Class 3: 5.90 - 7.80mm. Echogenicity: Class 1: 40.90 - 63.99 pixels; Class 2: 64.00 - 93.99 pixels; Class 3: 94.00 - 121.95 pixels. Heterogeneity: Class 1: 10.40 - 15.24 pixels; Class 2: 15.25 - 19.54 pixels; Class 3: 19.55 25.25 pixels. ${ }^{a, b}$ Different letters indicate indicate difference among the tone classes $(\mathrm{P}<0.05)$. ${ }^{\text {c d }}$ Different letters indicate a tendency for difference among the echogenicity classes $(\mathrm{P}=0.10)$.

When included in regression models as continuous variables, consistency, tone, and echogenicity had no effect $(\mathrm{P}=0.84, \mathrm{P}=0.13$ and $\mathrm{P}=0.24$, respectively) on the approval of boars. Nevertheless, the heterogeneity affected the approval of boars $(\mathrm{P}=0.02)$, with a significant $(\mathrm{P}<0.0001)$ area under the curve $(\mathrm{AUC}=0.71)$ and a cut-off value of 16.8 pixels. Based on this cut-off value, two groups of heterogeneity were formed: low heterogeneity ( $<16.8$ pixels) and high heterogeneity $(\geq 16.8$ pixels $)$. The percentage of approved boars in the group of high heterogeneity was lower than in the group of low heterogeneity $(56.81 \%$ and $64.83 \%$, respectively; $\mathrm{P}=0.04$; Figure 3 ). 


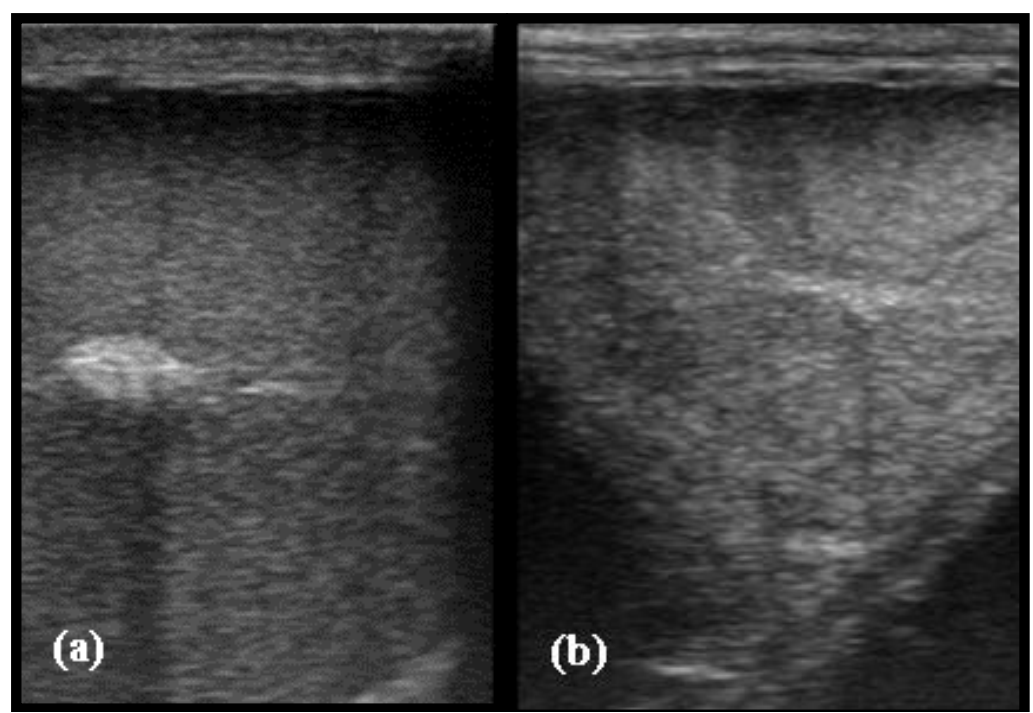

Figure 3. Ultrasonographic image viewed in the transverse plane representing testicles of an approved boar with low heterogeneity ( $\mathrm{a}-16.7$ pixels) and of a disapproved boar with high heterogeneity (b-25.8 pixels).

A further analysis of heterogeneity revealed that the percentage of approved boars was influenced by a significant interaction $(\mathrm{P}=0.01)$ between the groups of heterogeneity and tone classes (Table
4). A lower percentage of approved boars was observed when the boars belonged to class 1 of tone (soft testicles) and to the group of high testicular heterogeneity $(\mathrm{P}=0.01)$.

Table 4. Effect of the interaction $(\mathrm{P}=0.01)$ between groups of testicular heterogeneity and tone classes on the percentage of approved boars

\begin{tabular}{cccc}
\hline Tone Class & $\begin{array}{c}\text { Low heterogeneity } \\
(<16.8 \text { pixels })\end{array}$ & $\begin{array}{c}\text { High heterogeneity } \\
(\geq 16.80 \text { pixels })\end{array}$ & P value \\
\hline Class 1 $(2.68-4.00 \mathrm{~mm})$ & 77.78 & 47.73 & 0.01 \\
Class 2 $(4.01-5.89 \mathrm{~mm})$ & 68.9 & 62.43 & 0.16 \\
Class 3 $(5.90-7.80 \mathrm{~mm})$ & 37.50 & 42.50 & 0.98 \\
\hline
\end{tabular}

The interaction between the groups of heterogeneity and echogenicity classes tended $(\mathrm{P}=0.06)$ to affect the percentage of approved boars (Table 5). In the class 1 (low echogenicity), the percentage of approved boars was lower within the group of high heterogeneity. The interaction between the groups of heterogeneity and consistency classes had no effect $(\mathrm{P}=0.41)$ on the percentage of approved boars.

Table 5. Effect of the interaction $(\mathrm{P}=0.06)$ between groups of testicular heterogeneity and echogenicity classes on the percentage of approved boars

\begin{tabular}{lccc}
\hline Echogenicity Class & $\begin{array}{c}\text { Low heterogeneity } \\
(<16.8 \text { pixels })\end{array}$ & $\begin{array}{c}\text { High heterogeneity } \\
(\geq 16.80 \text { pixels })\end{array}$ & P value \\
\hline Class 1 (40.90 - 63.99 pixels) & 77.50 & 50.00 & 0.02 \\
Class 2 (64.00 - 93.99 pixels) & 60.87 & 61.96 & 0.40 \\
Class 3 (94.00 - 121.95 pixels $)$ & 53.85 & 40.82 & 0.45 \\
\hline
\end{tabular}

\section{DISCUSSION}

A complete breeding soundness should be routinely performed in studs aiming to identify boars that need to be culled. For practical reasons, evaluation methods that are accurate and easy to execute need to be tested and applied. In the present study, a large number of boars was evaluated to verify the usefulness of testicular traits in establishing thresholds that would 
further allow the identification of boars with low sperm quality. Moreover, as per our knowledge, this is the first study that suggests the importance of testicular parenchyma heterogeneity for boar sperm morphology.

The percentage of adult boars $(40.30 \%)$ that exceeded the thresholds of sperm abnormalities was similar to the results $(36.7 \%)$ of Schulze et al. (2014). It is noteworthy that the acceptance criteria and strictness for sperm abnormalities vary among different countries. The criteria suggested by CBRA (Manual..., 2013) consider distal cytoplasmic droplets as a non-pathologic defect, even though it is well known that distal droplets can affect boar fertility (Waberski et al., 1994). Therefore, we adapted the thresholds suggested by CBRA (Manual..., 2013) and expected a higher percentage of disapproved boars. The criteria used by Schulze et al. (2014), based on umbrella organization of pig production in Germany (ZDS, 2005), may have led to the slightly lower disapproval of boars. Nevertheless, the high percentage of disapproved boars found in both studies demonstrates the importance of establishing standard examination in the routine of studs, promoting early detection of boars with compromised sperm morphology.

There was no significant correlation between testicular consistency and sperm abnormalities in boars in the present investigation, which was in agreement with the study by Fitzpatrick et al. (2002) in bulls. The testicular consistency is commonly determined by manual palpation and the testes should ideally be of firm and uniform tissue or have a firm-elastic texture (Althouse, 2014). From the 402 boars examined, most of them $(71.39 \%)$ presented a firm-elastic testicular consistency (score varying from 2.25 to 3.0), $1.74 \%$ had very soft testicles (score varying from 1.0 to 2.0 ) and none had very hard testicles (score higher than 4.5). Since the boars were under a normal routine procedure of semen collection, those with severe sperm abnormalities had probably already been removed leading to a narrow possibility of finding testicular stiffness or softness. This situation may have contributed to the fact that the testicular consistency, examined by manual palpation, had no effect on the approval of boars.

Despite the subjectivity of the scores obtained by manual palpation, the evaluation of testicular consistency is very important, due to the possibility of detecting testicular degeneration. The significant correlation observed between manual palpation and tonometry $(r=0.62)$ suggests that tonometry can be explored as a complementary exam in breeding soundness examination. Some authors have already considered the objective evaluation of testicular consistency by tonometry (Esbenshade et al., 1979; Mahone et al., 1979). The high correlation $(\mathrm{r}=0.89-0.99)$ found among different examiners (Hahn et al., 1969) has demonstrated the objectivity of testicular tone evaluation in bulls.

A positive correlation between tone and the percentage of morphologically abnormal sperm cells has been reported for bulls aging from 17 to 150 months (Hahn et al., 1969). In contrast, this correlation was not significant in the present study and in bulls aging approximately 16 months (Kastelic et al., 2001). It can be inferred that the evaluation of old bulls could lead to the significant correlation observed by Hanh et al. (1969), since the advanced age is associated with higher percentage of sperm abnormalities (Schulze et al., 2014). Moreover, older boars have higher chance to be exposed to injury agents during their long stay in the stud, consequently increasing the chance of having testicular damage compared to younger boars.

A tendency of reduction in the percentage of approved boars was observed in the group with high testicular echogenicity (class $3 ; \geq 94.0$ pixels). Sperm abnormalities are commonly associated with hypo-echogenicity, since Arteaga et al. (2005) verified a decreased testicular echogenicity at 14 to 28 days after insulation and a subsequent increase in abnormal spermatozoa in bulls. Testicular fibrosis in boars is hard to diagnose without anatomy assessment, and the ultrasonographic findings depend on the stage of the disease (Gnemmi and Lefebvre, 2009; Úbeda et al., 2010). In most cases in which boars present low sperm quality and are eliminated without a specific cause, different degrees of fibrosis and inflammatory focus are found (Úbeda et al., 2010). Therefore, we can speculate that extreme cases of fibrosis had a narrow possibility to be found under normal routine of boar studs because males are probably culled before the process reaches an extreme degree. 
In a recent study, five out of the 26 boars examined by ultrasound scanning presented some alteration (19.23\%) such as mild to moderate hydrocele and hyperechoic mass in testicular parenchyma (Pinho et al., 2018). In the present study, 33 boars $(8.21 \%)$ showed alterations such as hyperechoic mass in testicular parenchyma or atrophy. It was expected that these alterations would reduce the approval of boars, but no difference $(\mathrm{P}=0.42)$ was observed between those with and without alterations (66.0\% and $73.9 \%$ of approval, respectively; data not shown). It is possible that not all alterations detected by ultrasound scanning were severe enough to compromise sperm cell morphology and be diagnosed (Gnemmi and Lefebvre, 2009). It is possible that boars with chronical degenerative fibrosis and inflammatory focus would be more prone to spermatogenesis disruption (Úbeda et al., 2010), but they have likely already been eliminated from the stud.

The association between the heterogeneity of the testicular parenchyma and the percentage of sperm abnormalities has not shown consistent results when evaluated through a correlation analysis. In our study, the heterogeneity was weakly correlated with sperm abnormalities $(r=$ 0.10 ), but in dogs no significant correlation was reported (Moxon et al., 2015; England et al., 2017), whereas a negative correlation $(\mathrm{r}=-0.73)$ was observed in rams (Ahmadi et al., 2012). When the heterogeneity of the testicular parenchyma was included in a logistic regression model as a continuous variable, we confirmed that more homogeneous testes are associated with higher sperm quality (Cartee et al., 1986). The AUC (0.71) observed reveals a moderate potential of heterogeneity in distinguishing the boars with more sperm abnormalities. It would be interesting to test the effectiveness of the cutoff value established for the heterogeneity (16.8 pixels) in younger boars when they are being selected to enter in a boar stud.

The degeneration of testicles influences sperm quality and produces an alteration in testicular consistency and echogenicity (Van Camp, 1997). However, the cases of attenuated or moderate degenerative process may heal after the removal of the injury causing agent. The lower percentage of approved boars in those with higher tone indicates that the stiffness caused by the scarring process can be detected by tonometry. The lower percentage of boars approved in the class of higher echogenicity suggests that processes like fibrosis or atrophy of testicular tissue can be revealed by ultrasonographic evaluation. On the other hand, in the acute degenerative process, the tone of testes is very soft and the fact that lesser boars were approved in the group with low tone associated with high heterogeneity reveals that boars with the acute degenerative process may be detected when the evaluation of tonometry and heterogeneity are combined. Furthermore, the importance of using more parameters to evaluate the contribution of parenchyma alterations on sperm quality was evidenced by the reduction in the number of boars approved among those with hypo-echogenic testicles in combination with a more heterogeneous parenchyma.

\section{CONCLUSIONS}

The evaluation of consistency and parenchymal ultrasound scanning can be tools used as a screening basis to identify boars with compromised sperm quality. Although high tone, echogenicity or heterogeneity, when considered separately, were associated with fewer boars approved, the ultrasound evaluation (heterogeneity) combined with tonometry provides more reliable information regarding the impact of testicular parenchymal alteration on the morphological quality of sperm cells. Due to the economic impact that a boar generates, further investigations need to be performed to verify if the methods can be used to discard boars during the selection, reducing costs and optimizing the use of boars with high sperm quality.

\section{ACKNOWLEDGEMENTS}

The authors are grateful to CAPES for financial support.

\section{REFERENCES}

AHMADI, B.; LAU, C.P.S.; GIFFIN, J. et al. Suitability of epididymal and testicular ultrasonography and computerized image analysis for assessment of current and future semen quality in the ram. Exp. Biol. Med., v.237, p.186-193, 2012.

ALTHOUSE, G.C. Applied andrology in swine. In: CHENOWETH, P.J.; LORTON, S.P. (Eds.). Animal andrology: theories and applications. Oxfordshire: CAB International, 2014. p.404-417. 
ARTEAGA, A.A.; BARTH, A.D.; BRITO, L.F. Relationship between semen quality and pixelintensity of testicular ultrasonograms after scrotal insulation in beef bulls. Theriogenology, v.64, p.408415, 2005.

CARTEE, R.; POWE, T.; GRAY, B. et al. Ultrasonographic evaluation of normal boar testicles. Am. J. Vet. Res., v.47, p.2543-2548, 1986.

CASPARI, K.; HENNING, H.; SCHALLER, C. et al. Semen quality and quantity in a boar with a complex hydrocele. J. Swine Health Prod., v.20, p.174-178, 2012.

CLARK, S.; SCHAEFFER, D.; ALTHOUSE, G. Bmode ultrasonographic evaluation of paired testicular diameter of mature boars in relation to average total sperm numbers. Theriogenology, v.60, p.1011-1023, 2003.

COULTER, G.; FOOTE, R. Bovine testicular measurements as indicators of reproductive performance and their relationship to productive traits in cattle: a review. Theriogenology, v.11, p.297-311, 1979.

ENGLAND, G.C.; BRIGHT, L.; PRITCHARD, B. et al. Canine reproductive ultrasound examination for predicting future sperm quality. Reprod. Domest. Anim., v.52, p.202-207, 2017.

ESBENSHADE, K.; SINGLETON, W.; CLEGG, E.; JONES, H. Effect of housing management on reproductive development and performance of young boars. J. Anim. Sci., v.48, p.246-250, 1979.

FITZPATRICK, L.; FORDYCE, G.; MCGOWAN, M. et al. Bull selection and use in northern Australia: Part 2. Semen traits. Anim. Reprod. Sci., v.71, p.39-49, 2002.

FLOWERS, W. Management of boars for efficient semen production. J. Reprod. Fertil., v.52, p.67-78, 1997.

FORD, J.; WISE, T. Assessment of pubertal development of boars derived from ultrasonographic determination of testicular diameter. Theriogenology, v.75, p.241-247, 2011.

GNEMMI, G.; LEFEBVRE, R.C. Ultrasound imaging of the bull reproductive tract: an important field of expertise for veterinarians. Vet. Clin. Food Anim., v.25, p.767-779, 2009.

HAHN, J.; FOOTE, R.; CRANCH, E. Tonometer for measuring testicular consistency of bulls to predict semen quality. J. Anim. Sci., v.29, p.483-489, 1969.
KASTELIC, J.; COOK, R.; PIERSON, R.; COULTER, G. Relationships among scrotal and testicular characteristics, sperm production, and seminal quality in 129 beef bulls. Can. J. Vet. Res., v.65, p.111, 2001.

KNOX, R.; LEVIS, D.; SAFRANSKI, T.; SINGLETON, W. An update on North American boar stud practices. Theriogenology, v.70, p.1202-1208, 2008.

MAHONE, J.; BERGER, T.; CLEGG, E.; SINGLETON, W. Photoinduction of puberty in boars during naturally occurring short day lengths. J. Anim. Sci., v.48, p.1159-1164, 1979.

MANUAL para exame andrológico e avaliação de sêmen animal. 3.ed. Belo Horizonte: CBRA, 2013. $87 \mathrm{p}$.

MOXON, R.; BRIGHT, L.; PRITCHARD, B. et al. Digital image analysis of testicular and prostatic ultrasonographic echogenicity and heterogeneity in dogs and the relation to semen quality. Anim. Reprod. Sci., v.160, p.112-119, 2015.

PINHO, R.O.; CAMILO, B.S.; LIMA, D.M. et al. The use of ultrasonography in the reproductive evaluation of boars. Reprod. Domest. Anim., v.53, p.393-400, 2018

SCHULZE, M.; BUDER, S.; RÜDIGER, K. et al. Influences on semen traits used for selection of young AI boars. Anim. Reprod. Sci., v.148, p.164-170, 2014.

SHIPLEY, C.F. Breeding soundness examination of the boar. Swine Health Prod., v.7, p.117-120, 1999.

ÚDEBA, J.L.; FALCETO, M.V.; DAHMANI, Y. et al. Practical review on reproductive testis pathology in boar. In: INTERNATIONAL PIG VETERINARY SOCIETY CONGRESS, 21., 2010, Vancouver. Proceedings...Vancouver. [s.n.], 2010. p.71. (Abstract)

VAN CAMP, S.D. Common causes of infertility in the bull. Vet. Clin. N. Am. Food Anim. Pract., v.13, p.203231, 1997.

WABERSKI, D.; MEDING, S.; DIRKSEN, G. Fertility of long-term-stored boar semen: Influence of extender (Androhep and Kiev), storage time and plasma droplets in the semen. Anim. Reprod. Sci., v.36, p.145-151, 1994.

ZDS - Zentralverbandes der deutschen schweineproduktion. 2005. Available in: <http://www.zds-bonn.de/anforderungenan>.

Accessed 8 Feb. 2018. 